\title{
MODEL INTEGER LINIEAR PROGRAMMING (ILP) DALAM PEMECAHAN TRAVELING SALESMAN PROBLEM (TSP) (STUDI KASUS : PT. PARIS JAYA MANDIRI - AMBON)
}

\author{
Daniel B. Paillin ${ }^{1}$, Johan M Tupan ${ }^{2}$ \\ 1Jurusan Teknik Industri Fakultas Teknik Universitas Pattimura, Ambon 97234 \\ Email : Daniel.paillin@fatek.unpatti.ac.id \\ 2 Jurusan Teknik Industri Fakultas Teknik Universitas Pattimura, Ambon 97234 \\ Email : johan.tupan@fatek.unpatti.ac.id
}

\begin{abstract}
Abstrak. Traveling Salesman Problrm (TSP) merupakan suatu permasalahan penentuan rute kendaraan dengan mencari jarak tempuh minimum dari titik awal menuju semua titik tujuan dan kembali lagi pada titik awal dengan asumsi bahwa semua titik tujuan yang akan dilalui hanya dikunjungi sebanyak satu kali untuk memperoleh rute optimal distribusi produk. Pada penelitian ini mencoba menggunakan metode Integer Linier Programming (ILP) dalam menyelesaikan permasalahan TSP. Tolak ukur yang digunakan pada metode ini adalah jarak antar outlet dimulai dari mengukur masing-masing jarak dari gudang menuju oulet dan kembali ke gudang yang tersebar pada wilayah distribusi Sirimau 1 dan 2 serta wilayah distribusi Nusaniwe. Hasil penelitian menunjukan bahwa metode Integer Liniear Programming memiliki output effisiensi rute tempuh baik dari segi jarak sebesar $26.32 \%$ dan waktu total $7.42 \%$ dari rute regular perusahaan.
\end{abstract}

Kata kunci: rute optimal, traveling salesman problem, integer linier programming

\begin{abstract}
Abstrak. Traveling Salesman Problem (TSP) is a matter of determining vehicle routes by finding the minimum distance from the starting point to all destination points and returning to the starting point with the assumption that all destination points to be traversed are only visited once to get the optimal route of product distribution. This research tries to use the Integer Linear Programming (ILP) method in solving the TSP problem. Benchmarks used in this method are the distance between outlets starting from measuring each distance from the warehouse to the outlet and returning to the warehouse which is spread in the Sirimau 1 and 2 distribution areas and the Nusaniwe distribution area. The results showed that the Integer Linear Programming method has output efficiency of the route both in terms of distance of $26.32 \%$ and a total time of $7.42 \%$ of the company's regular routes.
\end{abstract}

Keywords: optimal route, traveling salesman problem, integer linier programming

\section{PENDAHULUAN}

Seiring dengan perkembangan zaman yang terus meningkat dengan pesat juga diimbangi pula dengan munculnya produk-produk yang lebih kreatif, berinovasi dan terus berkembang. Dengan terus berinovasi, perusahaan menjadikan penyaruran atau pendistribusian sebagai hal yang penting untuk dikembangkan karena dengan pendistribusian yang baik, produk yang dihasilkan akan sampai kepada konsumen dengan cepat, tepat dan dalam kondisi yang baik.

Distribusi merupakan suatu kegiatan untuk memindahkan produk dari pihak supplier ke pihak konsumen dalan suatu supply chain (Chopra, 2010 ). Pendistribusian yang dilakukan haruslah diimbangi dengan penentuan rute yang tepat sehingga proses perpindahan produk tersebut tepat dan optimal. Banyak sekali rute yang dapat dipilih perusahaan dalam mendistribusikan produknya, dan 
membutuhkan biaya yang berbeda-beda pula, untuk itu butuh suatu metode yang dapat menganalisa pendistribusian produk agar lebih bisa meminimalisasi dari segi waktu, jarak, biaya dan tenaga (A. Effendi, 2016).

Bagi suatu perusahaan komoditas tertentu, pengiriman barang meruapakan suatu bagian penting dalam jalannya sebuah perusahan komoditas tertentu yang dihadapkan pada sebuah masalah yaitu menentukan rute terpendek bagi armada kendaraan untuk memasarakan produknya kebebrapa agen atau toko yang sudah ditentukan tempatnya. Masalah ini disebut Treveling Salesman Problem (TSP). TSP adalah suatu perjalanan salesman dari satu tempat (kota) asalnya mengunjungi n-tempat (kota) tepat satu kali kemudian kembali ke tempat (kota) asalnya dengan jarak yang minimum. Ini bertujuan untuk meminimumkan biaya operasional yang dikeluarakan perusahaan. Dalam TSP salesman tidak diperbolehkan kembali ketempat asal sebelum semua temapat dikunjungi dalam satu kali perjalanan. Fungsi objektif TSP adalah meminimumkan jarak total rute yang dikunjungi salesman. Masalah mTSP sering dikenal dengan istilah Vehichel Routing Problame (VRP). Pada TSP, terdapat sejumlah tempat dan seorang salesman yang harus menemukan jalur terpendek untuk mengunjungi setiap tempat tepat satu kali dan selesai ditempat asal.

PT. Paris Jaya Mandiri perupakan salah satu perusahaan distribusi yang berada di Ambon. Untuk wilayah Ambon pendistribusian PT. Paris Jaya Mandiri meliputi kecamatan Sirimau dan kecamatan Nusaniwe. Jenis produk yang didistribusikan oleh perusahaan ini meliputi produk Nestle, Loreal, Jhonson Hygiene dan Unilever.

Pengantaran diklasifikasikan menjadi beberapa channel distribusi yaitu channel wholesaler, midwives, medical, hotel, self service combo, small store dan beberapa jenis channel lainnya. Untuk jenis produk Nestle sendiri terbagi atas beberapa brand seperti Bear Brand, Nescaffe, Nestle, Dancow dll. Pendistribusian dalam setiap kendaraan hanya dapat dilaksanakan sebanyak satu kali yaitu dari depot ke setiap agen kemudian kembali lagi ke depot.

Perusahaan memiliki umlah joutlet yang tersebar di 39 titik di lokasi yang bebeda untuk channel small store produk Nestle. Proses pengantaran produk pada channel small store menggunakan 1 mobil tipe colt diesel dengan kapasitas 320 karton dan harus memenuhi permintaan dari 67 outlet tiap minggunya.
Dalam melakukan proses distribusi, perusahaan belumlah bisa menemukan cara yang pasti untuk meminimumkan total jarak tempuh untuk 67 outlet tersebut. Padahal jika total jarak tempuh diminimumkan maka proses distribusi produk tersebut dapat dilakukan dengan optimal dan efisien. Hal tersebut juga pastinya dapat meminimumkan biaya dan waktu dalam melakukan proses pendistribusian.

Untuk mengatasi masalah tersebut, maka saleman dituntut untuk meminimumkan jarak rute yang seefisien mungkin agar mencapai total jarak tempuh kendaraan yang minimum sehingga proses pendistribusian dapat dilakukan dengan efektif. Salah satu metode yang akan digunakan untuk permasalahan tersebut adalah metode Treveling Salesman Problem (TSP), dengan memberikan model pemograman Linier Integer atau Integer Linier Programming (ILP) yang dapat membantu dalam menyelesaikan masalah TSP. ILP adalah masalah optimisasi dengan fungsi objektif dan kendala yang linier serta variable integer.

\section{BAHAN DAN METODE}

\subsection{Traveling Salesman Problem}

Hoffman dan Wolfe (1985), mendefinisikan TSP sebagai berikut: TSP is one which has commanded much attention of mathematicians and computer scientists specifically because it is so easy to describe and so difficult to solve. The problem can simply be stated as: if a Traveling salesman wishes to visit exactly once each of a list of $m$ cities (where the cost of Traveling from city $i$ to city $j$ is Cij) and then return to the home city, what is the least costly route the Traveling salesman can take?". Selain itu sulitnya menyelesaikan Traveling Salesman Problem sebagai salah satu masalah optimasi yang cukup kompleks juga disebabkan ruang solusi (solution space) yang mungkin untuk kebanyakan masalah optimasi terlalu besar dan kemungkinan terjadinya pencarian yang tidak terarah cukup besar sehingga sulit untuk dipecahkan atau diselesaikan. Teknik pencarian solusi tingkat tinggi untuk memangkas atau menyederhanakan ruang pencarian juga tidak menjamin dihasilkannya suatu solusi yang optimal. Dengan kata lain, sulit mendesain suatu teknik pemecahan masalah yang efektif untuk menyelesaikan masalah optimasi seperti Traveling Salesman Problem (Paillin dan Tupan 2018).

Persoalan yang dihadapi TSP ialah bagaimana merencanakan total jarak yang minimum. Untuk menyelesaikan persoalan tersebut, tidak mudah 
dilakukan karena terdapat ruang pencarian dari sekumpulan permutasi sejumlah kota. Maka TSP kemudian dikenal dengan persoalan Non Polinomial. Gambaran sederhana dari pengertian TSP adalah sebagai berikut:

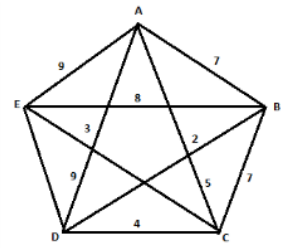

Gambar 1. Posisi kota-kota yang akan dilewati

Kota - kota pada gambar 1 masing-masing mempunyai koordinat $(\mathrm{x}, \mathrm{y})$ sehingga jarak antar kedua kota dapat dihitung dengan rumus euclidean:

$d_{(i, j)}=\sqrt{(x i-x j)^{2}+(y i-y j)^{2}}$

keterangan:

$\mathrm{xi}=$ koordinat $\mathrm{x}$ kota $\mathrm{i}$

$\mathrm{x} j=$ koordinat $\mathrm{x}$ kota $\mathrm{j}$

$\mathrm{y} i=$ koordinat $\mathrm{y}$ kota $\mathrm{i}$

$\mathrm{yj}=$ koordinat $\mathrm{y}$ kota $\mathrm{j}$

Setelah jarak yang menghubungkan tiap kota diketahui maka dicari rute terpendek dari jalur yang akan dilewati untuk kembali ke kota awal. Permasalahan yang terjadi pada kasus Traveling salesman problem dapat dimodelkan sebagai graph tak-berarah dan berbobot. Berikut representasi banyaknya lintasan tertutup TSP dalam graph:

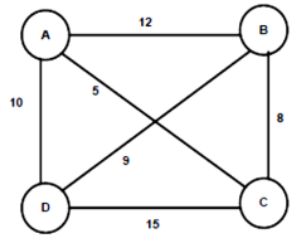

Gambar 2. Graph K berbobot

Dari Graph tersebut dicari banyaknya lintasan tertutup dari titik A kembali lagi ke titik A. Terdapat 6 lintasan tertutup pada Graph K yaitu, A-B-C-D-A, A-D-C-B-A, A-C-D-B-A, A-B-D-C-A, A-D-B-C$A$, dan A-C-B-D-A, sehingga banyaknya lintasan tertutup (s) dapat dicari dengan :

$$
\mathrm{s}=(n-1) \text { ! }
$$

Dalam Graph K, rusuk-rusuknya tidak berarah sehingga $d(A, B)=d(B, A)$. banyaknya lintasan menjadi :

$$
\mathrm{s}=((\mathrm{n}-1) !) / 2
$$

Karena sirkuit A-B-C-D-A = A-D-C-B-A, A-C$\mathrm{D}-\mathrm{B}-\mathrm{A}=\mathrm{A}-\mathrm{C}-\mathrm{D}-\mathrm{B}-\mathrm{A}$, dan A-C-B-D-A = A-D-B-C-
A. Jadi banyaknya semua kemungkinan lintasan tertutup ditentukan dengan rumus (2.).

Asumsi dasar dari model TSP adalah setiap titik hanya akan dilalui sebanyak satu kali dan kembali lagi pada titik awal/gudang, dan jarak antar kedua titik merupakan jarak terpendek yang akan dilalui. Berikut dijelaskan formulasi model TSP untuk meminimumkan rute. Didefinisikan $G(N, A)$ adalah Graph tak berarah, dengan $N=\{v 1, v 2, v 3, \ldots ., v n\}$ merupakan himpunan titik yang merepresentasikan $n$ pelanggan, dan $v 1$ merepresentasikan kantor, sedangkan $A=\{(v i, v j) \mid v i, v j \in V, i \neq j\}$ adalah himpunan sisi yang menghubungkan antar titik, yang merepresentasikan ruas jalan penghubung antar titik.

Selanjutnya didefinisikan variabel keputusan $X i j$ yang merepresentasikan ada tidaknya perjalanan dari titik $i$ ke $j$ dalam suatu rute sebagai berikut :

$X i j=\left\{\begin{array}{l}1, j i k a \text { terdapat perjalanan kendaraan dari } i \text { ke } j \\ 0, j i k a \text { tidak ada perjalanan kendaraan dari } i \text { ke } j\end{array}\right.$ Jika Z merupakan fungsi tujuan TSP, maka fungsi tujuan $\mathrm{Z}$ dirumuskan dengan meminimumkan

$$
Z=\sum_{i=1}^{n} \sum_{j=1}^{n} \mathrm{C}_{\mathrm{ij}} \mathrm{X}_{\mathrm{ij}}
$$

dengan batasan kendala,

$$
\begin{aligned}
& \sum_{i=1}^{n} X_{i j}=1 \quad(i=1,2,3, \ldots, N) \\
& \sum_{j=1}^{n} X_{i j}=1 \quad(j=1,2,3, \ldots, N) \\
& X_{i j}=0 \text { atau } 1
\end{aligned}
$$

Batasan yang pertama dan kedua memastikan bahwa rute yang terpilih mendatangi setiap kota 1 kali dan meninggalkan kota tersebut 1 kali.

\subsection{Integer Linier Programming}

Program bilangan bulat (integer programming) merupakan bentuk perluasan dari linear programming. Persoalan IP menginginkan solusi yang didapat berupa bilangan bulat, bukan berupa bilangan pecahan. Contoh persoalan yang sering ditemui misalnya menentukan banyaknya barang elektronik yang harus diproduksi, banyaknya unit rumah yang akan dibangun pada suatu proyek perumahan, banyaknya orang yang diperlukan untuk mengerjakan suatu proyek, dan sebagainya. Integer programming memiliki model matematis yang sama dengan model linear programming pada umumnya, tetapi ditambah batasan bahwa variabelnya harus bilangan bulat. (Hillier andLieberman, 2001) 
Bentuk lain dari masalah integer programming adalah binary integer programming (BIP). Dalam persoalan binary integer programming nilai variabel keputusannya berupa bilangan biner (0 atau 1$)$. Dalam aplikasi sehari-hari, masalah binary integer programming menyangkut masalah pengambilan keputusan, di mana jika solusi yang didapat berupa angka 1 yang menyatakan "ya" atau angka 0 yang menyatakan "tidak". Bentuk umum dari BIP yaitu :

$$
\begin{aligned}
& \text { Kendala } \\
& \sum_{j=1}^{n} a_{i j} x_{j}(\leq, \geq,=) b_{i} \\
& i=1,2, \ldots, m \\
& j=1,2, . ., n \\
& x_{j}=0 \text { atau } 1
\end{aligned}
$$$$
\text { Optimalkan : } Z=\sum_{j=1}^{n} c_{j} x_{j}
$$

Berikut ini adalah tahapan penelitian yang akan dilakukan sebagai berikut:

- Observasi dilakukan untuk melihat keadaan nyata di perusahaan.

- Identifikasi masalah dan tujuan. Langkah ini dilakukan agar peneliti lebih memahami masalah yang terjadi secara lebih spesifik dan mampu menetapkan tujuan yang akan dicapai untuk mencari solusi dari permasalahan yang terjadi.

- Pengumpulan data. Tahap ini dilakukan untuk mengumpulkan variabel - variabel yang dibutuhkan dalam penelitian. Dalam penelitian ini yang menjadi variabel terikat adalah penentuan rute distribusi dan variabel bebas adalah lokasi dan permintaan outlet, data jarak tempuh, dan data waktu tempuh.

- Pembahasan TSP Pada bagian ini dijelaskan tentang pengolahan data pencarian rute dengan bantuan software.

- Pemeriksaan hasil jarak tempuh sebelum dan sesudah pengolahan dengan TSP.

- Analisa perbandingan hasil. Bagian ini memberikan penjelasan terkait dengan perbandingan rute awal dan rute baru perusahaan yang memberikan rincian penghematan jarak dan waktu tempuh yang diperoleh dari hasil olahan data. Pada tahap ini dilakukan pemeriksaan apakah jarak yang dirancang lebih minimum dari jarak menggunakan metode TSP.

- Kesimpulan dan saran. Bagian ini dimaksudkan untuk menjawab tujuan penelitian dengan memberikan solusi masalah distribusi bagi perusahaan yaitu merancang rute baru dengan jarak dan waktu tempuh minimum.

\section{HASIL DAN PEMBAHASAN}

\subsection{Deskripsi Sistem Pendistribusian Produk Nestle di Kota Ambon}

Kegiatan distribusi produk Nestle yang dilakukan oleh PT. Paris Jaya Mandiri mencakup 2 wilayah yang ada di Kepulauan Ambon yaitu wilayah kecamatan Sirimau dan kecamatan Nusaniwe. Cakupan wilayah kecamatan Sirimau dimulai dari Galala - Air Mata Cina dan cakupan wilayah kecamatan Nusaniwe dimulai dari Waihaong - Seri. Berikut merupakan gambaran wilayah distribusi produk Nestle di pulau Ambon.

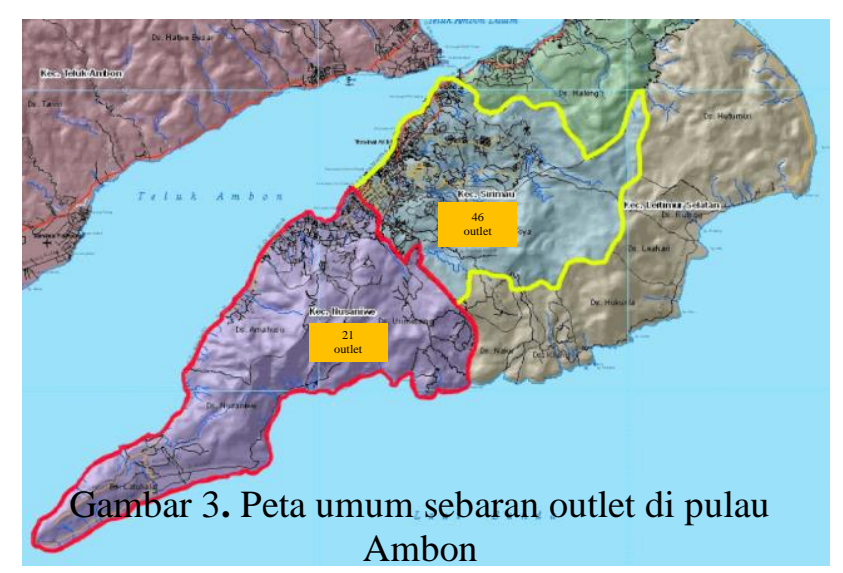

\section{Data Lokasi dan Permintaan Outlet}

Berikut merupakan daftar lokasi dari kode customer (KC) dan demand (D) dari outlet yang akan dikunjungi.KC (PJM) PT. Paris Jaya Mandiri

\section{Data Jarak Tempuh}

Data jarak tempuh adalah data jarak dari depot PT. Paris Jaya Mandiri menuju sejumlah oulet yang dituju dan juga jarak antaroutlet. Perhitungan jarak diperoleh dengan rumus Euclidean $d_{(i j)}=\sqrt{(x i-x j)^{2}+(y i-y j)^{2}}$ dengan titik $\mathrm{x}$ dan $\mathrm{y}$ merupakan titik latitude dan longitude outlet yang diperoleh melalui google maps. 
Tabel 1. Lokasi dan jumlah permintaan outlet PT. Paris Jaya Mandiri Ambon

\begin{tabular}{|c|c|c|c|c|c|c|c|}
\hline кс & Nama Outlet & Alamat & $\begin{array}{c}\mathbf{D}(\mathbf{k r t}) \\
/ \text { /minggu }\end{array}$ & кс & Nama Outlet & Alamat & $\begin{array}{c}\mathbf{D}(\mathbf{k r t}) \\
\text { /minggu }\end{array}$ \\
\hline $\mathrm{Cl}$ & $\begin{array}{l}\text { Cahaya Fatan } \\
\text { - Bapi }\end{array}$ & Pertokoan Batu Merah & 16 & C35 & Anda & Jl. Ahmad Yani & \\
\hline $\mathrm{C} 2_{2}$ & Al-Bagir & Pertokoan Batu Merah & 18 & C36 & Surya Indah Toko & Batu Gajah & \\
\hline C3 3 & Mas Sri & Pertokoan Batu Merah & 30 & C37 & Prison & Batu Meja & 22 \\
\hline C4 & Nuryanti & Pertokoan Batu Merah & 14 & C38 & Biasa Toko & Jl. Setia Budi & 8 \\
\hline C5 & & Pertokoan Batu Merah & & C39 & Berkat & & 9 \\
\hline с6 & Manna Toko & Gabla & 26 & C40 & Maluku Jaya Abadi Toko & Diponegoro (Kel. Ahusen) & 15 \\
\hline c7 & Kios Jukis & Gakala & 9 & C41 & Anugerah Toko & Dekat Hotel Pasifik & 5 \\
\hline c8 & & Tantui & 18 & $\mathrm{C} 42$ & The Indah Toko & A. Y. Patty & 50 \\
\hline & Fandi & Mardika & 10 & C43 & Ci Nona & Yos Soedarso & \\
\hline C10 & Melissa 2 & Mardika & 36 & C44 & Sovia Toko & & 15 \\
\hline C11 & Ko Han & Mardika & 50 & C45 & Andi Kios & Air Mata Cina & 8 \\
\hline $\begin{array}{l}\mathrm{Cl} 22 \\
\mathrm{Cl} 3\end{array}$ & $\begin{array}{l}\text { Adin } \\
\text { Akbar }\end{array}$ & $\begin{array}{l}\text { Marrika } \\
\text { Mardika }\end{array}$ & $\begin{array}{l}18 \\
12\end{array}$ & $\begin{array}{l}\text { C46 } \\
\text { C47 }\end{array}$ & $\begin{array}{l}\text { Lily Toko } \\
\text { Kios Anes }\end{array}$ & $\begin{array}{l}\text { A.Y.P.Patty } \\
\text { Depan Par Tagalaya }\end{array}$ & ${ }_{13}^{22}$ \\
\hline & $\begin{array}{l}\text { Akbar } \\
\text { Om Mon }\end{array}$ & $\begin{array}{l}\text { Mardoka } \\
\text { Belakang Soya }\end{array}$ & $\begin{array}{l}12 \\
42\end{array}$ & C48 & $\begin{array}{l}\text { Kos Anes } \\
\text { Cempaka Toko }\end{array}$ & $\begin{array}{l}\text { Depan Pasar Iagalaya } \\
\text { Dr. Kayadoe }\end{array}$ & $\begin{array}{l}13 \\
10\end{array}$ \\
\hline $\mathrm{C} 15$ & Liana & Tanah Tinggi & 15 & C49 & Safari Toko & Dr. Kayadoe & 17 \\
\hline $\mathrm{C} 16$ & Meter Toko & D. I. Panjaitan & 7 & C50 & Empi Toko & Dr. Kayadoe & 20 \\
\hline C17 & $\begin{array}{l}\text { Toko Mitra } \\
\text { Jaya }\end{array}$ & Jl. Pantai Mardika & 16 & C51 & Darren & Dr. Kayadoe & 39 \\
\hline C18 & $\begin{array}{l}\text { Apotek } \\
\text { Mannasuka }\end{array}$ & Jl. Pantai Mardika & 10 & C52 & Kios Ema & Dr. Kayadoe & 13 \\
\hline C19 & Fata Rahmat & Jl. Pantai Mardika & 13 & C53 & Damai Saparua Toko & Dr. Kayadoe & 14 \\
\hline $\mathrm{C} 20$ & Toko Ivan & Jl. Pantai Mardika & 25 & C54 & Spout Toko & Dr. Kayadoe & 21 \\
\hline $\mathrm{C} 21$ & $\begin{array}{l}\text { Empat Jaya } \\
\text { TToko }\end{array}$ & Jl. Pantai Mardika & 19 & C55 & Mikael Toko & Gudang Arang & 11 \\
\hline $\mathrm{C} 22$ & Teki Toko & Karpan & 15 & C56 & Annyong Toko & Kusu - Kusu & 11 \\
\hline $\mathrm{C} 23$ & Harmoni & Wara & 6 & C57 & Sinar Mulia Toko & Benteng & 19 \\
\hline $\mathrm{C} 24$ & Kios 2 Putri & Kebun Cengkeh & 4 & C58 & Benteng Indah Toko & Benteng & 11 \\
\hline $\mathrm{C} 25$ & Balvis Kios & BTN Kanawa & 11 & C59 & Jaya Abadi Toko & & 18 \\
\hline $\begin{array}{l}\mathrm{C} 26 \\
\mathrm{C} 27\end{array}$ & $\begin{array}{l}\text { Haikal } \\
\text { Mas No }\end{array}$ & $\begin{array}{l}\text { Kebun Cengkeh } \\
\text { Skip }\end{array}$ & $\begin{array}{l}11 \\
12\end{array}$ & $\begin{array}{l}\text { C60 } \\
\text { C61 }\end{array}$ & $\begin{array}{l}\text { Natsepa Kios } \\
\text { Linda Toko }\end{array}$ & $\begin{array}{l}\begin{array}{l}\text { Amahausu } \\
\text { OSM }\end{array} \\
\text { os }\end{array}$ & $\begin{array}{l}6 \\
7\end{array}$ \\
\hline C28 & Mustika Toko & JL. Rijali No. 40 & 10 & $\mathrm{C} 62$ & Beringin Baru & Jl. Nn Saar Sopacua & 12 \\
\hline C29 & Aping Toko & Batu Meja & 8 & $\mathrm{C}_{63}$ & Kace Toko & Wainitu & 8 \\
\hline C30 & Sakura Toko & Bere - Bere & 14 & $\mathrm{C} 64$ & Baru Toko & Talake & 7 \\
\hline $\begin{array}{l}331 \\
C 32\end{array}$ & Jhon Coa & Bere - Bere & 12 & C65 & Aliang Toko & Talake & 26 \\
\hline $\begin{array}{c}C_{32} \\
C_{323}\end{array}$ & Rejeki Toko & $\begin{array}{l}\text { Bere- Bere } \\
\text { Kayu Puth }\end{array}$ & $\begin{array}{l}12 \\
18\end{array}$ & $\begin{array}{l}666 \\
667\end{array}$ & $\begin{array}{l}\text { Olive } \\
\text { Umer Tako }\end{array}$ & $\begin{array}{l}\text { Waihaong } \\
\end{array}$ & ${ }_{20}^{14}$ \\
\hline $\begin{array}{c}C_{33} \\
\text { C34 }\end{array}$ & $\begin{array}{l}\text { Alan } \\
\text { Jerry Cell }\end{array}$ & $\begin{array}{l}\text { ayyu unthi } \\
\text { Jl. Ahmad Yani }\end{array}$ & $\begin{array}{c}18 \\
8 \\
\end{array}$ & & Umar Toko & I. Sultan Babulah & \\
\hline
\end{tabular}

Tabel 2. Matriks jarak antar outlet wilayah Sirimau 1

\begin{tabular}{|c|c|c|c|c|c|c|c|c|c|c|c|c|c|c|c|c|c|c|c|c|c|c|c|c|}
\hline \multirow{2}{*}{\multicolumn{25}{|c|}{ 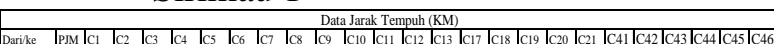 }} \\
\hline & & & & & & & & & & & & & & & & & & & & & & & & \\
\hline & & & & & & & & & & & & & & & & & & & & & & & & \\
\hline $\mathrm{Cl}$ & & & & & & & & & & & & & & & & & & & & & & & & \\
\hline $\mathrm{C} 2$ & 2.80 & & & & & & & & & & & & & & & & & & & & & & & \\
\hline $\mathrm{C} 3_{3}$ & 2.83 & & 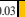 & & & & & & & & & & & & & & & & & & & & & \\
\hline C4 & 2.900 & 0.09 & & 0.09 & & & & & & & & & & & & & & & & & & & & \\
\hline $\mathrm{C5}$ & 2.811 & 0.03 & 1.03 & & 0.07 & & & & & & & & & & & & & & & & & & & \\
\hline & 1.50 & 2.98 & 2.98 & & 3.07 & & & & & & & & & & & & & & & & & & & \\
\hline $\mathrm{Cl}^{\mathrm{C}}$ & $|1.40|$ & 3.06 & 3.06 & & & & 0.14 & & & & & & & & & & & & & & & & & \\
\hline $\mathrm{CB}$ & \begin{tabular}{|l|l|} 
\\
\end{tabular} & 2.36 & 2.36 & 2.37 & 2.45 & 2.39 & 0.62 & 0.72 & & & & & & & & & & & & & & & & \\
\hline C9 & $2.60 \mid$ & 0.13 & 0.13 & & & & 3.02 & & & & & & & & & & & & & & & & & \\
\hline $\mathrm{C} 10$ & 3.100 & & 1.27 & & & & & & & 0.191 & & & & & & & & & & & & & & 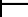 \\
\hline & 3.100 & & & & & & $\frac{3.21}{3}$ & 3.30 & & & & & & & & & & & & & & & & \\
\hline $\mathrm{Cl1}$ & 3.122 & & & & & & & & & & & & & & & & & & & & & & & \\
\hline $\mathrm{Cl} 13$ & 3.12 & & & & & & & 3.24 & & & & & & & & & & & & & & & & \\
\hline $\mathrm{Cl1}$ & $\begin{array}{l}4277 \\
\end{array}$ & & $\begin{array}{l}349 \\
\end{array}$ & & & & 3,466 & 3.55 & & & & & & 0.31 & & & & & & & & & & \\
\hline $\mathrm{C} 18$ & 3.500 & & $\begin{array}{l}499 \\
\end{array}$ & & & & 3,466 & 3.54 & & & & & & & 0.10 & & & & & & & & & \\
\hline $\begin{array}{ll}\mathrm{C} \\
\end{array}$ & 3.30 & & 1.500 & & $\frac{3.41}{2}$ & & 3,48 & 3.55 & & & & & $\frac{1.32}{2}$ & & & & & & & & & & & \\
\hline $\mathrm{C} 20_{2}$ & 3.41 & & 1.51 & $\begin{array}{l}.49 \\
\end{array}$ & & $\begin{array}{l}348 \\
\end{array}$ & 3,48 & 3.56 & & & & & 0.34 & 0.34 & 0.14 & & 0.06 & & & & & & & \\
\hline $\mathrm{C} 21$ & 3.34 & & 336 & & & & $\sqrt{3,32}$ & 3400 & & & & & & 0211 & & & & & & & & & & \\
\hline C41 & 3300 & 0.527 & 52 & 154 & 846 & 500 & 6321 & 3.42 & & |ant & & & 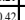 & 102 & 1040 & 1500 & & & & & & & & \\
\hline C44 & 4781 & & 23 & & & & & 429 & & & & & & & & $\mid 7.76$ & & & & & & & & \\
\hline C43 & 4000 & & & & & & & 420 & & & & 93 & 2097 & $\mid 0.97$ & 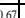 & 1066 & $\frac{1658}{106}$ & & & & & & & \\
\hline C44 & 4.56 & & & & & & 3.90 & 3.98 & & & & & .75 & & & 0.44 & 0.43 & & & 0.74 & & & & \\
\hline$C_{44}$ & 485 & & 81 & & & & & & 121 & & & & & & & & & & & & & & & \\
\hline & & & .22 & & & & & & & & & & & & & & & & & & & & & \\
\hline
\end{tabular}

Tabel 3. Matriks jarak antar outlet wilayah Sirimau 2

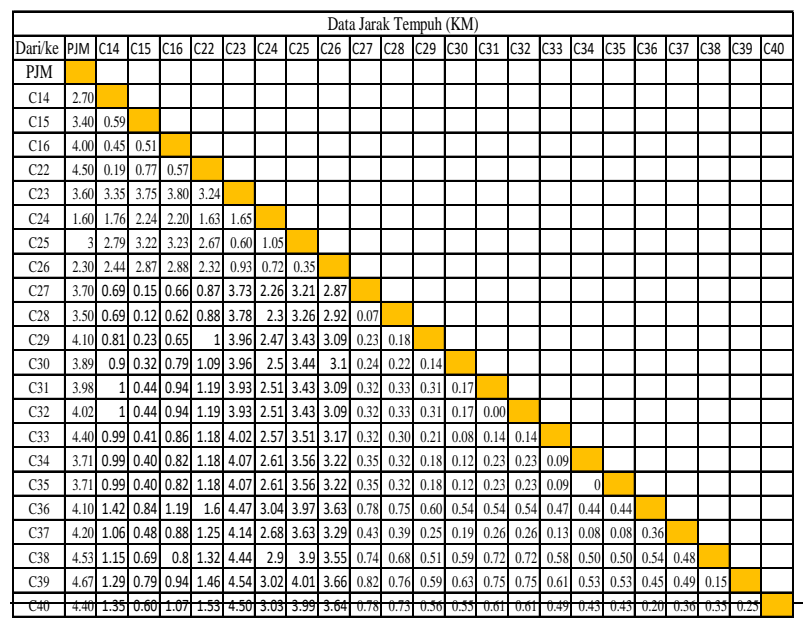

Tabel 4 Matriks jarak antar outlet wilayah Sirimau 2

\begin{tabular}{|c|c|c|c|c|c|c|c|c|c|c|c|c|c|c|c|c|c|c|c|c|c|c|c|}
\hline \multicolumn{24}{|c|}{ Data Jarak Tempuh (KM) } \\
\hline Dari/Ke & PJM C & & C48 & C49 & C50 & & C5 & & & & & & & C58 & & C60 & C61 & & C63 & & $665 \mathrm{Cc}$ & & C67 \\
\hline PJM & & & & & & & & & & & & & & & & & & & & & & & \\
\hline C47 & 5.20 & & & & & & & & & & & & & & & & & & & & & & \\
\hline C48 & & 0.73 & & & & & & & & & & & & & & & & & & & & & \\
\hline C49 & 5.60 & & 0.46 & & & & & & & & & & & & & & & & & & & & \\
\hline C50 & 5.80 & & 0.26 & & & & & & & & & & & & & & & & & & & & \\
\hline C51 & 5.82 & & 0.25 & 0.24 & 0.0 & & & & & & & & & & & & & & & & & & \\
\hline $\mathrm{C} 52$ & 5.82 & & 0.25 & 0.24 & 0.0 & & & & & & & & & & & & & & & & & & \\
\hline C53 & 6.33 & 1.02 & 0.32 & 0.75 & 0.5 & 0. & 7.0. & & & & & & & & & & & & & & & & \\
\hline C54 & 6.60 & 1.23 & 0.55 & 0.97 & 0.8 & 0.8 & 00 & & & & & & & & & & & & & & & & \\
\hline C55 & 7.03 & 1.62 & 1.16 & 1.44 & 1.3 & 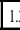 & 61. & & 890 & .73 & & & & & & & & & & & & & \\
\hline C56 & & 0.71 & 0.36 & 0.51 & 0.4 & 0. & 60 & & 42 & 56 & 1.93 & & & & & & & & & & & & \\
\hline C57 & 6.90 & 1.55 & 1.01 & 1.34 & 1.2. & 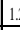 & \begin{tabular}{l|l}
3 & 1 \\
\end{tabular} & & 71 & 52 & 1.23 & 0.84 & & & & & & & & & & & \\
\hline C58 & 6.91 & 1.70 & 1.15 & 1.49 & 1.3. & 1. & $7 \mid$ & & & & 1.23 & 0.99 & 0.15 & & & & & & & & & & \\
\hline C59 & 7.70 & 1.95 & 1.30 & 1.71 & 1.5 & 1. & 41 & & 98 & 75 & .66 & 1.25 & 0.51 & 0.43 & & & & & & & & & \\
\hline $\mathrm{C} 60$ & & 4.05 & 3.32 & 3.78 & 3.5 & 3. & 5 & & 04 & & 2.92 & 3.43 & 2.79 & 2.70 & 2.28 & & & & & & & & \\
\hline $\mathrm{C} 61$ & 6.40 & & 0.66 & 0.95 & 0.8 & $0.8 x-3 x-3$ & $5 \mid 0$. & & 44 & & 1.50 & 0.44 & 0.40 & 0.55 & 0.85 & 3.10 & & & & & & & \\
\hline $\mathrm{C} 62$ & 6.50 & & 0.73 & 1.04 & 0.9 & & & & 48 & & 1.43 & 0.54 & 0.31 & 0.45 & 0.76 & 6.02 & 0.09 & & & & & & \\
\hline $\mathrm{C63}$ & 5.80 & & 0.31 & 0.28 & 0.2 & 0.2 & 80 & & 53 & .72 & 1.16 & 0.23 & 1.06 & 1.21 & 1.45 & 53.57 & 0.67 & 0.76 & & & & & \\
\hline C64 & 5.70 & & \begin{tabular}{|l|l|} 
\\
\end{tabular} & & 0.6 & 0. & 0 & & 93 & 10 & 1.33 & 0.53 & \begin{tabular}{|l}
1.31 \\
\end{tabular} & \begin{tabular}{|l|l|} 
\\
\end{tabular} & \begin{tabular}{|l|l|} 
\\
\end{tabular} & 63.96 & \begin{tabular}{|l|l}
0.92 \\
\end{tabular} & 21.01 & 10.43 & & & & \\
\hline C65 & 5.73 & & 0.76 & & 0.6 & 0. & & & & & 133 & 0.54 & 1.31 & 1.44 & \begin{tabular}{|l}
1.76 \\
\end{tabular} & \begin{tabular}{|l|l|l}
6.97 \\
\end{tabular} & 0.92 & 20 & & 0.02 & & & \\
\hline $\mathrm{C} 66$ & 5.30 & & \begin{tabular}{|l}
.25 \\
\end{tabular} & & \begin{tabular}{|l|l} 
\\
\end{tabular} & & & & .40 & .53 & 1.57 & \begin{tabular}{|l|}
0.99 \\
\end{tabular} & 1.62 & 1.74 & 2,111 & 14.37 & \begin{tabular}{|l|l}
1.27 \\
\end{tabular} & 87.36 & 60.94 & & 0.50 & & \\
\hline $\mathrm{C} 67$ & 5 & 0.065 & 1.25 & 0.87 & 1.0 & & 101 & & 46 & .61 & 1.75 & 1.05 & 1.77 & 1.90 & \begin{tabular}{|l|}
2.25 \\
\end{tabular} & \begin{tabular}{|l|l|l|} 
\\
\end{tabular} & 1.40 & 40 & 90.55 & \begin{tabular}{|l|l|} 
\\
\end{tabular} & $\mid 0.51$ & 0.25 & \\
\hline
\end{tabular}

\section{Waktu Tempuh}

Waktu tempuh merupakan waktu yang dibutuhkan oleh kendaraan dalam proses pendistribusian barang. Kecepatan kendaraan yang digunakan adalah $40 \mathrm{~km} / \mathrm{jam}$. Rumus perhitungan waktu tempuh sebagai berikut:

Waktu tempuh $=\frac{d_{(i j)}}{v} \times 60$ menit

Keterangan: $d_{i j}$ : Jarak tempuh $(\mathrm{km})$

$$
v: \text { Kecepatan kendaraan }(\mathrm{km} / \mathrm{jam})
$$

Untuk melakukan kegiatan pengangkutan dan bongkar muat barang tersebut dibutuhkan waktu 0.15 menit tiap kartonnya sehingga perhitungan waktu total dapat diperoleh dengan menjumlahkan waktu tempuh dengan waktu bongkar muat tiap karton pada masing - masing outlet (Waktu tempuh total)

\subsection{Model ILP Untuk TSP}

- Model matematik untuk wilayah Sirimau 1

Minimumkan $Z=\sum_{i=1}^{25} \sum_{j=1}^{25} C_{i j} X_{i j}$

dengan batasan,

$$
\begin{aligned}
& \sum_{i=1}^{25} X_{i j}=1 \quad(j=1,2,3, \ldots .25) \\
& \sum_{j=1}^{25} X_{i j}=1 \quad(i=1,2,3, \ldots .25) \\
& X_{i j}=0 \text { atau } 1
\end{aligned}
$$

- Model matematik untuk wilayah Sirimau 2 
Minimumkan $Z=\sum_{i=1}^{23} \sum_{j=1}^{23} C_{i j} X_{i j}$ dengan batasan,

$\sum_{i=1}^{23} X_{i j}=1 \quad(j=1,2,3, \ldots . .23)$

$\sum_{j=1}^{23} X_{i j}=1 \quad(i=1,2,3, \ldots .23)$

$X_{i j}=0$ atau 1

- Model matematik untuk wilayah Nusaniwe

Minimumkan $Z=\sum_{i=1}^{22} \sum_{j=1}^{22} C_{i j} X_{i j}$

dengan batasan,

$\sum_{i=1}^{22} X_{i j}=1 \quad(j=1,2,3, \ldots . .22)$

$\sum_{j=1}^{22} X_{i j}=1 \quad(i=1,2,3, \ldots .22)$

$X_{i j}=0$ atau 1

\subsection{Rute Reguler/ Rute Awal PT. Paris Jaya Mandiri}

Rute awal perusahaan merupakan rute yang biasanya dilalui oleh petugas distribusi. Untuk pengolahan jarak pada rute tersebut dilakukan berdasarkan rute perusahaan yang telah ada dimulai dari gudang menuju outlet pertama, dan dilanjutkan ke outlet berikutnya sampai ke outlet yang terakhir sesuai dengan urutan yang telah ditetapkan oleh perusahaan. Saat ini perusahaan memilliki 6 rute distribusi yang biasanya dilalui oleh petugas distribusi. Hasil pengolahan data rute regular perusahaan diperoleh dengan menjumlahkan jarak tempuh dan menjumlahkan waktu tempuh yang dialui oleh petugas distribusi berdasarkan data jarak dan waktu tempuh yang dapat dilihat pada tabel 5 . Sedangkan untuk waktu total (Wt) didapat dari jumlah waktu tempuh dengan waktu bongkar muat barang pada setiap outlet

Tabel 5 Hasil data reguler

\begin{tabular}{|c|c|c|c|}
\hline \multirow[b]{2}{*}{ Rute } & \multirow[b]{2}{*}{ Destinasi Outlet } & \multicolumn{2}{|c|}{ Jumlah } \\
\hline & & $\operatorname{Jarak}(\mathrm{Km})$ & $\begin{array}{l}\text { Total Waktu } \\
\text { (Menit) }\end{array}$ \\
\hline 1 & PJM - C1 - C2 - C3 - C4 - C5 - C6 - C7 - C8 - PJM & 8 & 60,6 \\
\hline 2 & $\mathrm{PJM}-\mathrm{C} 9-\mathrm{C} 10-\mathrm{C} 11-\mathrm{C} 12-\mathrm{C} 13-\mathrm{C} 16-\mathrm{C} 17-\mathrm{C} 18-\mathrm{C} 19-\mathrm{C} 20-\mathrm{C} 21-\mathrm{PJM}$ & 7,28 & 75,72 \\
\hline 3 & PJM-C22-C23-C24-C25-C26-PJM & 12,19 & 32,38 \\
\hline 4 & $\begin{array}{l}\text { PJM - C14-C27-C28-C15-C29-C } 30-\mathrm{C} 31-\mathrm{C} 32-\mathrm{C} 33-\mathrm{C} 34-\mathrm{C} 35- \\
\mathrm{C} 36-\mathrm{C} 37-\mathrm{C} 38-\mathrm{C} 39-\mathrm{C} 40-\mathrm{C} 41-\mathrm{PJM}\end{array}$ & 10,55 & 85,42 \\
\hline 5 & PJM - C42-C46-C43-C44-PJM & 9,81 & 55,81 \\
\hline 6 & $\begin{array}{l}\text { PJM - C45-C56-C47-C48-C49-C50-C51-C52-C53-C54-C55-C57 } \\
- \text { C } 58-\mathrm{C} 59-\mathrm{C} 60-\mathrm{C} 61-\mathrm{C} 62-\mathrm{C} 63-\mathrm{C} 64-\mathrm{C} 65-\mathrm{C} 66-\mathrm{C} 67-\mathrm{PJM}\end{array}$ & 22,93 & 131,98 \\
\hline & Total & 70,76 & 441,9 \\
\hline
\end{tabular}

\subsection{Penentuan Rute dengan Model ILP}

Pemecahan masalah Traveling Salesman Problem, dalam kasus penentuan rute terpendek dari suatu aktivitas distribusi dapat dilakukan dengan menggunakan model ILP menggunakan software Lingo 11. Berdasarkan pengelompokan wilayah distribusi yang telah disusun dapat dibuat rute baru dengan jarak tempuh minimum sesuai dengan kelompok wilayah distribusi tersebut. Untuk kelompok wilayah 1 dengan jumlah destinasi outlet sebanyak 24 dapat diperoleh 2 rute distribusi, kelompok wilayah 2 dengan jumlah outlet sebanyak 22 diperoleh 2 rute distribusi dan kelompok wilayah 3 dengan jumlah outlet sebanyak 21 outlet dapat diperoleh 1 rute distribusi. Selanjutnya, dilakukan perhitungan rute terpendek dengan menggunakan model ILP. Secara ringkas hasil pengolahan dengan ILP menggunakan software Lingo 11.dapat dilihat pada tabel 6 berikut

Tabel 6 Hasil Pengolahan Data Lingo TSP

\begin{tabular}{|c|c|c|c|}
\hline \multirow[b]{2}{*}{ Rute } & \multirow[b]{2}{*}{ Destinasi Outlet } & \multicolumn{2}{|c|}{ Jumlah } \\
\hline & & Jarak (Km) & $\begin{array}{c}\text { Total Waktu } \\
\text { (Menit) }\end{array}$ \\
\hline 1 & PJM-C1-C2-C5-C4-C13-C12-C21-C3-C8-C7-C6-PJM & 7,02 & 73,83 \\
\hline 2 & $\begin{array}{l}\mathrm{PJM}-\mathrm{C} 41-\mathrm{C} 45-\mathrm{C} 46-\mathrm{C} 42-\mathrm{C} 43-\mathrm{C} 44-\mathrm{C} 20-\mathrm{C} 18-\mathrm{C} 19-\mathrm{C} 17-\mathrm{C} 10-\mathrm{C} 11 \\
-\mathrm{C} 9-\mathrm{PJM}\end{array}$ & 9,08 & 101,82 \\
\hline 3 & PJM - $\mathrm{C} 14-\mathrm{C} 16-\mathrm{C} 15-\mathrm{C} 22-\mathrm{C} 24-\mathrm{C} 26-\mathrm{C} 25-\mathrm{C} 23-\mathrm{PJM}$ & 9,51 & 47,57 \\
\hline 4 & $\begin{array}{l}\text { PJM - C28-C29-C } 30-\mathrm{C} 32-\mathrm{C} 35-\mathrm{C} 34-\mathrm{C} 38-\mathrm{C} 39-\mathrm{C} 40-\mathrm{C} 36-\mathrm{C} 33- \\
\mathrm{C} 37-\mathrm{C} 31-\mathrm{C} 27-\mathrm{PJM}\end{array}$ & 8,55 & 63,82 \\
\hline 5 & $\begin{array}{l}\text { PJM - C66-C64-C63-C62-C } 48-\mathrm{C} 49-\mathrm{C} 50-\mathrm{C} 51-\mathrm{C} 47-\mathrm{C} 52-\mathrm{C} 53- \\
\text { C59- C58-C57-C54-C56-C61-C60-C55-C67-C65-PJM }\end{array}$ & 17,98 & 122,07 \\
\hline & Total & 52,14 & 409,11 \\
\hline
\end{tabular}

\subsection{Analisa Perbandingan Hasil Perhitungan Rute awal Dengan Menggunakan Model ILP}

Untuk memperoleh jarak tempuh yang paling optimal bagi perusahaan, maka dilakukan perbandingan antara rute awal dengan rute hasil model ILP. Berikut merupakan perbandingan hasil jarak tempuh dan Total waktu antara rute awal dan hasil model ILP

Tabel 7 Perbandingan hasil perhitungan rute awal dengan hasil model ILP 


\begin{tabular}{|c|c|c|c|c|}
\hline \multirow[b]{2}{*}{ R } & \multirow[b]{2}{*}{ Rute } & \multirow[b]{2}{*}{ Destinasi Outlet } & \multicolumn{2}{|c|}{ Jumlah } \\
\hline & & & $\operatorname{Jarak}(\mathrm{Km})$ & $\begin{array}{c}\text { Total Waktu } \\
\text { (Menit) }\end{array}$ \\
\hline u & 1 & PJM - C1 - C2 - C3 - C4 - C5 - C6 - C7 - C8 - PJM & 8 & 60,6 \\
\hline e & 2 & $\mathrm{PJM}-\mathrm{C} 9-\mathrm{C} 10-\mathrm{C} 11-\mathrm{C} 12-\mathrm{C} 13-\mathrm{C} 16-\mathrm{C} 17-\mathrm{C} 18-\mathrm{C} 19-\mathrm{C} 20-\mathrm{C} 21-\mathrm{PJM}$ & 7,28 & 75,72 \\
\hline${ }^{R}$ & 3 & PJM - C22-C23-C24-C25-C26-PJM & 12,19 & 32,38 \\
\hline g & 4 & $\begin{array}{l}\text { PJM-C14-C27-C28-C15-C29-C30-C31-C32-C33-C } 34-\mathrm{C} 35- \\
\text { C36-C37-C } 38-\mathrm{C} 39-\mathrm{C} 40-\mathrm{C} 41-\mathrm{PJM}\end{array}$ & 10,55 & 85,42 \\
\hline $\begin{array}{l}\text { l } \\
\text { e }\end{array}$ & 5 & PJM - C42 - C46-C43-C44-PJM & 9,81 & 55,81 \\
\hline \multirow[t]{4}{*}{$\mathrm{r}$} & 6 & $\begin{array}{l}\text { PJM - C } 45-\mathrm{C} 56-\mathrm{C} 47-\mathrm{C} 48-\mathrm{C} 49-\mathrm{C} 50-\mathrm{C} 51-\mathrm{C} 52-\mathrm{C} 53-\mathrm{C} 54-\mathrm{C} 55-\mathrm{C} 57 \\
-\mathrm{C} 58-\mathrm{C} 59-\mathrm{C} 60-\mathrm{C} 61-\mathrm{C} 62-\mathrm{C} 63-\mathrm{C} 64-\mathrm{C} 65-\mathrm{C} 66-\mathrm{C} 67-\mathrm{PJM}\end{array}$ & 22,93 & 131,98 \\
\hline & & Total & \\
\hline & & & & \\
\hline & Rute & Destinasi Outlet & Jarak (Km) & $\begin{array}{c}\text { Total Waktu } \\
\text { (Menit) }\end{array}$ \\
\hline \multirow{3}{*}{$\begin{array}{l}\mathrm{M} \\
\mathrm{o} \\
\mathrm{d} \\
\mathrm{e} \\
\mathrm{I}\end{array}$} & 1 & $\mathrm{PJM}-\mathrm{C} 1-\mathrm{C} 2-\mathrm{C} 5-\mathrm{C} 4-\mathrm{C} 13-\mathrm{C} 12-\mathrm{C} 21-\mathrm{C} 3-\mathrm{C} 8-\mathrm{C} 7-\mathrm{C} 6-\mathrm{PJM}$ & 7,02 & 73,83 \\
\hline & 2 & $\begin{array}{l}\mathrm{PJM}-\mathrm{C} 41-\mathrm{C} 45-\mathrm{C} 46-\mathrm{C} 42-\mathrm{C} 43-\mathrm{C} 44-\mathrm{C} 20-\mathrm{C} 18-\mathrm{C} 19-\mathrm{C} 17-\mathrm{C} 10-\mathrm{C} 11 \\
-\mathrm{C} 9-\mathrm{PJM}\end{array}$ & 9,08 & 101,82 \\
\hline & 3 & $\mathrm{PJM}-\mathrm{C} 14-\mathrm{C} 16-\mathrm{C} 15-\mathrm{C} 22-\mathrm{C} 24-\mathrm{C} 26-\mathrm{C} 25-\mathrm{C} 23-\mathrm{PJM}$ & 9,51 & 47,57 \\
\hline \multirow[t]{3}{*}{$\begin{array}{l}\mathrm{I} \\
\mathrm{L} \\
\mathrm{P}\end{array}$} & 4 & $\begin{array}{l}\text { PJM-C28-C29-C } 30-\mathrm{C} 32-\mathrm{C} 35-\mathrm{C} 34-\mathrm{C} 38-\mathrm{C} 39-\mathrm{C} 40-\mathrm{C} 36-\mathrm{C} 33- \\
\text { C37-C31-C27-PJM }\end{array}$ & 8,55 & 63,82 \\
\hline & 5 & $\begin{array}{l}\text { PJM - C66-C64-C63-C62-C } 48-\mathrm{C} 49-\mathrm{C} 50-\mathrm{C} 51-\mathrm{C} 47-\mathrm{C} 52-\mathrm{C} 53- \\
\mathrm{C} 59-\mathrm{C} 58-\mathrm{C} 57-\mathrm{C} 54-\mathrm{C} 56-\mathrm{C} 61-\mathrm{C} 60-\mathrm{C} 55-\mathrm{C} 67-\mathrm{C} 65-\mathrm{PJM}\end{array}$ & 17,98 & 122,07 \\
\hline & & Total & 52,14 & 409,11 \\
\hline
\end{tabular}

Dari tabel diatas dapat dilihat bahwa rute regular dengan 6 rute sedangkan model ILP menghasilkan 5 rute. Untuk pengolahan jarak antara rute regular dengan model ILP memiliki hasil yang signifikan yaitu dengan selisih jarak sebesar 18.62 $\mathrm{Km}$ dengan persentase penghematan sebesar $26.32 \%$ dari rute regular. Selisih total waktu rute regular dengan model ILP adalah sebesar 32.8 menit dengan pesentase penghematan sebesar $7.42 \%$.

Untuk lebih memperjelas hasil perbandingan yang diperoleh antara rute regular dengan model ILP maka disajikan gambar grafik jarak pada gambar 4 berikut ini.

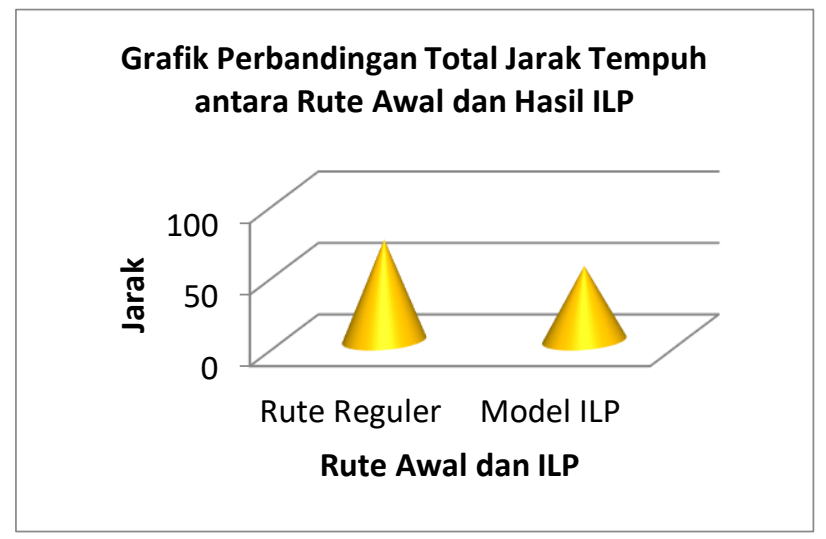

Gambar 4.. Grafik perbandingan total jarak tempuh

Sesuai dengan grafik diatas hasil olahan data dengan model ILP memberikan hasil jarak yang paling minimum, dimana metode ini mengalami pengurangan jarak tempuh yang lebih hemat dari rute awal

\section{KESIMPULAN}

Adapun tujuan dari penelitian ini adalah untuk merencanakan rute distribusi produk Nestle sehingga dapat ditempuh jarak tempuh yang optimal. Berdasarkan hasil pengolahan dan analisis data dari keempat metode yang digunakan maka dapat ditarik kesimpulan yaitu dipilih metode Integer Liniear Programming yang memiliki output effisiensi rute tempuh baik dari segi jarak sebesar $26.32 \%$ dan waktu total $7.42 \%$. Persentase penghematan ini juga menunjukkan terjadi penghematan jarak sebesar $18.62 \mathrm{Km}$ dengan penghematan total waktu tempuh selama 32.8 menit dari rute awal perusahaan. Dari hasil metode metode Two-way Exchange Improvement Heuristic yang dipilih terdapat 5 rute optimal distribusi produk Nestle sebagai berikut:

- Rute 1 : PJM-Cahaya Fatan-Al - Bagir-BlitarNuryanti -Akbar-Adin-Empat Jaya Toko-Mas Sri-Herley-Kios Julais-Manna Toko-PJM Total jarak tempuh adalah $7.02 \mathrm{Km}$ dengan total waktu adalah 73.83 menit.

- Rute 2 : PJM - Anugerah Toko - Andi Kios Kios Anes - The Indah Toko- Ci Nona - Sovia Toko - Toko Ivan- Apotek Mannasuka - Fata Rahmat - Toko Mitra Jaya - Melissa 2 - Ko Han - Fandi - PJM. Total jarak tempuh adalah 9.08 Km dengan total waktu adalah 101.82 menit

- Rute 3 : PJM -Om Mon - Meter Toko - Liana Teki Toko - Kios 2 Putri- Haikal- Balvis Kios Harmoni - PJM. Total jarak tempuh adalah 9.51 $\mathrm{Km}$ dengan total waktu adalah 47.57 menit.

- Rute 4 : PJM - Mustika Toko - Aping Toko Sakura Toko - Rejeki Toko - Anda- Jerry Cell Toko Biasa - Berkat- Maluku Jaya Abadi Toko Surya Indah Toko - Alan - Prison - Jhon Coa Mas No - PJM. Total jarak tempuh $8.55 \mathrm{Km}$ dengan total waktu 63.82 menit

- Rute 5 : PJM - Umar Toko - Aliang Toko - Baru Toko- Kace Toko - Safari Toko - Empi TokoDarren-Kios Ema - Cempaka Toko - Damai Saparua Toko - Spout Toko- Natsepa Kios - Jaya Abadi Toko - Benteng Indah Toko -Mikael Toko-Sinar Mulia Toko - Beringin Baru - Linda Toko - Annyong Toko - Lily Toko - Olive PJM. Total Jarak tempuh adalah $17.98 \mathrm{Km}$ dengan waktu tempuh 122.07 menit 


\section{UCAPAN TERIMA KASIH}

Penulis menyampaikan banyak terimakasih kepada Fakultas Teknik Universitas Pattimura yang telah memberikan dana penelitian PNBP tahun 2019 sehingga penelitian in I dapat terselesaikan dengan baik. Penulis juga menyampaikan banyak terimkasih kepada Filinda Sosebeko, Inka Lasamahu serta Rizki Anggraeni Utami Putri selaku mahasiswa bimbingan yang telah membantu dalam pengolahan data hingga penelitian ini da[at terselesaikan.

\section{DAFTAR PUSTAKA}

[1] Chopra, Sunil dan Peter Meindl., Supply chain management: Strategy, planning, and operatio $n s$. New Jersey: Prentice Hall, 2010

[2] Hillier, F \& Lieberman, G.J (2001). Introduction to Operation Research. Seventh Edition. Mc Graw Hill . New York, USA

[3] Hoffman, A.J. and Wolfe, P. "History" in The Trav eling Salesman Problem, E.L. Lawler, J.K. Lenstra, A.H.G. Rinooy Kan, and D.B. Shmoys, eds., John W iley, 1-16., 1985

[4] Paillin. D.B dan Tupan. J.M (2018). Pemecahan Traveling Salesman Problem Menggunakan Teknik Branch and Bound dan Cheapest Insertion Heuristic (Studi Kasus: PT. Paris Jaya Mandiri-Ambon). Prosiding Seminar dan Konfrensi Nasional IDEC. 110120.,Surakarta, 7-8 Mei 2018)

[5] Paillin, D. B dan Sosebeko I, Penentuan Rute Optim al Distribusi Produk Nestle dengan Metode TSP. Ju rnal ARIKA, Vol 11 No. 1. Pp.31-40, 2017 